\title{
Erwinia tasmaniensis sp. nov., a non-phytopathogenic bacterium from apple and pear trees
}

Correspondence
Klaus Geider
K.Geider@bba.de

\author{
Klaus Geider, ${ }^{1} \dagger$ Georg Auling, ${ }^{2}$ Zhiqiang Du, ${ }^{1}$ Vladimir Jakovljevic, ${ }^{1}$ \\ Susanne Jock ${ }^{1}$ and Beate Völksch ${ }^{3}$ \\ ${ }^{1}$ Max-Planck-Institut für Zellbiologie, Rosenhof, 68526 Ladenburg, Germany \\ ${ }^{2}$ Universität Hannover, Institut für Mikrobiologie, Schneiderberg 50, 30167 Hannover, Germany \\ ${ }^{3}$ Friedrich-Schiller-Universität Jena, Institut für Mikrobiologie, Neugasse 25, 07743 Jena, \\ Germany
}

\begin{abstract}
Bacteria were isolated from flowers and bark of apple and pear trees at three places in Australia. In Victoria, Tasmania and Queensland, strains with white colonies on nutrient agar were screened for dome-shaped colony morphology on agar with sucrose and were found to be closely related by several criteria. The isolates were not pathogenic on apples or pears. They were characterized by a polyphasic approach including microbiological and API assays as well as fatty acid methyl ester analysis, DNA-DNA hybridization and DNA sequencing. For molecular classification, the $16 \mathrm{~S}$ rRNA cistron and the conserved genes gpd and recA of these bacteria were investigated. Together with other taxonomic criteria, the results of these studies indicate that the bacteria belong to a novel separate species, which we propose to name Erwinia tasmaniensis sp. nov., with the type strain Et1/99 ${ }^{\top}\left(=\mathrm{DSM} 17950^{\top}=\right.$ NCPPB $\left.4357^{\top}\right)$. From DNA-DNA hybridization kinetics, microbiological characteristics and nucleotide sequence analyses, this species is related to pathogenic Erwinia species, but also to the epiphytic species Erwinia billingiae.
\end{abstract}

Colonization of flowers by Erwinia amylovora is considered to be a crucial step in establishment of most natural fire blight infections. The artificial increase of beneficial competing bacteria has often been proposed to control fire blight. The non-phytopathogenic epiphytic bacterium Pseudomonas fluorescens strain A506 has been used as a fire blight biocontrol agent, as well as Pantoea agglomerans (syn. Erwinia herbicola) strains for precolonization of flowers against fire blight (Johnson \& Stockwell, 2000). Here, we have selected bacteria from apple and pear trees in Australia for a white colony morphology and levan formation with sucrose. These features resemble properties of the fire blight pathogen E. amylovora (see review by Vanneste, 2000). A related Asian pear pathogen from Korea, Erwinia pyrifoliae (Kim et al., 1999, 2001), does not produce levan. The new isolates were classified by their $16 \mathrm{~S}$ rRNA gene sequence and by partial nucleotide sequences of two housekeeping genes.

†Present address: Biologische Bundesanstalt, Schwabenheimer Str. 101, D-69221 Dossenheim, Germany.

The GenBank/EMBL/DDBJ accession numbers for the 16S rRNA gene, gpd and recA sequences of strain Et1/99 ${ }^{\top}$ are AM055716AM055718.

Details of the fatty acid compositions of three of the novel strains and related strains and extended versions of the trees shown in Figs 1 and 2 are available as supplementary material in IJSEM Online.
Alignments of $g p d$ gene sequences of necrogenic Erwinia and Brenneria species have been described in detail for the clarification of phylogenetic relationships (Brown et al., 2000; $g p d$, encoding glyceraldehyde-3-phosphate dehydrogenase, was referred to as gapDH in this earlier study). Due to multiple cellular functions of the RecA protein (Kowalczykowski et al., 1994), the recA gene is highly conserved in bacteria at the amino acid sequence level. Nevertheless, several silent changes in the nucleotide sequence can be used for species differentiation (Lloyd \& Sharp, 1993). The former genus Erwinia has been dissected by microrestriction analysis of amplified recA PCR fragments (Waleron et al., 2002). The new isolates may contribute towards limiting the occurrence of fire blight in the Southern hemisphere.

\section{Isolation of strains in Australia}

In November 1999, we extracted pear flowers for levanproducing bacteria in the area of Knoxfield, Victoria, apple flowers in orchards near Hobart, Tasmania, and bark from apple trees taken in Applethorpe, Queensland, near Brisbane (Table 1), by suspending the plant tissue in a small amount of sterile water. Aliquots of the supernatants were spread on LB agar plates (with $50 \mu \mathrm{g}$ cycloheximide $\mathrm{ml}^{-1}$ to avoid fungal growth), which were incubated for 2 days at $28^{\circ} \mathrm{C}$. 
Table 1. Strains used in these studies

\begin{tabular}{|c|c|c|}
\hline Strain & Source, isolation & Reference \\
\hline \multicolumn{3}{|l|}{ Erwinia amylovora } \\
\hline Ea1/79 $(=$ DSM $17948=$ NCPPB 4359$)$ & Cotoneaster sp., Germany; isolated by W. Zeller & Falkenstein et al. (1988) \\
\hline CFBP $1232^{\mathrm{T}}\left(=\right.$ ATCC $\left.15580^{\mathrm{T}}\right)$ & Pear, England; deposited by R. A. Lelliott & - \\
\hline \multicolumn{3}{|l|}{ Erwinia billingiae } \\
\hline $\operatorname{Eb} 661^{\mathrm{T}}\left(=\mathrm{NCPPB} 661^{\mathrm{T}}\right)$ & Pear, England; isolated by E. Billing & Mergaert et al. (1999) \\
\hline \multicolumn{3}{|l|}{ Erwinia persicina } \\
\hline CFBP $3622^{\mathrm{T}}\left(=\right.$ ATCC $\left.35998^{\mathrm{T}}\right)$ & Tomato, Japan; deposited by D. J. Brenner & Hao et al. (1990) \\
\hline \multicolumn{3}{|l|}{ Erwinia pyrifoliae from Korea } \\
\hline Ep1/96 (=DSM 12162) & Asian pear (Pyrus pyrifolia); isolated by S.-L. Rhim & Kim et al. (1999) \\
\hline Ep16/96 ${ }^{\mathrm{T}}\left(=\mathrm{DSM} 12163^{\mathrm{T}}\right)$ & Asian pear ( $P$. pyrifolia); isolated by S.-L. Rhim & Kim et al. (1999) \\
\hline \multicolumn{3}{|l|}{ Erwinia rhapontici } \\
\hline CFBP $3618^{\mathrm{T}}\left(=\right.$ ATCC $\left.29283^{\mathrm{T}}\right)$ & Rhubarb, England; deposited by M. P. Starr & Hauben et al. (1998) \\
\hline \multicolumn{3}{|l|}{ Erwinia tasmaniensis sp. nov. } \\
\hline Et1/99 ${ }^{\mathrm{T}}\left(=\mathrm{DSM} 17950^{\mathrm{T}}=\mathrm{NCPPB} 4357^{\mathrm{T}}\right)$ & $\begin{array}{l}\text { Apple flowers, Tasmania, Australia; isolated by S. Jock } \\
\text { and K. Geider }\end{array}$ & This work \\
\hline Et2/99 $(=$ DSM $17949=$ NCPPB 4358$)$ & $\begin{array}{l}\text { Pear flowers, Victoria, Australia; isolated by S. Jock } \\
\text { and K. Geider }\end{array}$ & This work \\
\hline Et4/99 & $\begin{array}{l}\text { Apple bark, Queensland, Australia; isolated by S. Jock } \\
\text { and K. Geider }\end{array}$ & This work \\
\hline
\end{tabular}

From pear flowers in Victoria, 25 white colonies on agar plates with approx. 500 colonies were transferred to LB agar with $5 \%$ sucrose and all produced levan. In similar experiments with extracts from apple flowers in Tasmania, 12 of 25 were levan-positive. From extracted bark of apple trees (cultivar 'Fuji') in Queensland, we obtained approx. 200 yellow and 100 white colonies per plate, some of which were levan-positive (2/25). In initial microbiological characterization, the levan-producing isolates did not stain in a Gram treatment and lysed in 3\% KOH (Gregersen, 1978; Suslow et al., 1982), both properties of Gram-negative bacteria. They were also positive in the aminopeptidase reaction (Cerny, 1976; Bascomb \& Manafi, 1998) and were facultatively anaerobic, suggesting their classification in the genus Erwinia. Three isolated strains, Et1/99 ${ }^{\mathrm{T}}$ (isolated in Tasmania), Et2/99 (from Knoxfield, Victoria) and Et4/99 (from the Stanthorpe area in Queensland), were studied in detail. As strains Et1/99 and Et2/99 were isolated as the dominant bacteria by suspending apple or pear flowers in water, they should exist as epiphytes that colonize plant surfaces.

\section{Virulence assays}

For virulence assays on immature pear fruits, strains Et1/ $99^{\mathrm{T}}$, Et2/99 and Et4/99 were inoculated on slices of immature pear with toothpicks dipped into fully grown suspension cultures. In contrast to E. amylovora and E. pyrifoliae, no ooze production was seen after incubation for 1 week or longer. In assays with apple seedlings (cultivar 'Golden Delicious'), no necrotic symptoms were observed after inoculation with the novel strains and incubation of the seedlings for 2-3 weeks. Consequently, the isolates are nonpathogenic for common fire blight host plants.

\section{5 rRNA gene sequences}

For molecular classification of the novel strains, DNA fragments were amplified with three sets of PCR primers (Table 2). DNA bearing 16S rRNA gene sequences was obtained with the primers $\mathrm{fd} 2$ and $\mathrm{rP} 1$. The $1.4 \mathrm{~kb}$ amplification product was cloned into vector pGEM-T (Promega) and sequenced. The nucleotide sequences of the three novel strains were aligned with a series of 16S rRNA gene sequences from other Erwinia species and species of Pectobacterium, Pantoea and Brenneria (Fig. 1 and Supplementary Fig. S1 available in IJSEM Online). They were closely related and were separated from E. amylovora, E. pyrifoliae and Erwinia billingiae. Dendrograms were constructed with CLUSTAL $\mathrm{X}$ for Windows version 1.81 and MEGA 3.1 (Kumar et al., 2004). Phylogenetic distances were estimated by the method of Jukes \& Cantor (1969) and tree topology was inferred by the neighbour-joining method with a bootstrap value of 1000 . For reconstruction of phylogeny, the neighbour-joining and maximum-parsimony methods produced similar results. The $16 \mathrm{~S}$ rRNA gene sequences of strains Et1/99 ${ }^{\mathrm{T}}$, Et2/99 and Et4/99 possessed signature nucleotides identical to those described for the genus Erwinia (Hauben et al., 1998) [A, A, C, G, G, C, G, G, G, C, G, C, C, C and G at positions 408, 595, 599, 639, 646, 839, 847, 987, 988, 989, 1216, 1217, 1218, 1308 and 1329, according to the Escherichia coli 16S rRNA gene sequence numbering (GenBank accession no. J01695)]. A shift by one position was found for the indicative nucleotides A and C given by Hauben et al. (1998) for positions 594 and 598 in the 16S rRNA gene sequences of all Erwinia strains included in Fig. 1. Among the 16S rRNA gene sequences, those from E. amylovora, E. pyrifoliae, E. billingiae and Erwinia persicina exhibited sequence similarities 
Table 2. PCR primers applied in gene amplification

PCR primers GAP11 and GAP12c were used for strains Ea1/79 and Eb661.

\begin{tabular}{|c|c|c|}
\hline Primer & Sequence $\left(5^{\prime}-3^{\prime}\right)$ & Reference \\
\hline \multicolumn{3}{|c|}{ 16S rRNA gene } \\
\hline $\mathrm{fd} 2$ & AGAGTTTGATCATGGCTCAG & Weisburg et al. (1991) \\
\hline rP1 & ACGGTTACCTTGTTACGACTT & \\
\hline \multicolumn{3}{|l|}{ gpd } \\
\hline GAP1F & TGAAATATGACTCCACTCACGG & Brown et al. (2000) \\
\hline GAP1R & TAGAGGACGGGATGATGTTCTG & \\
\hline GAP11 & ACGGCACTGTAGAAGTC & This work \\
\hline GAP12c & CCAGTCTTTGTGAGACG & \\
\hline \multicolumn{3}{|l|}{$\operatorname{rec} A$} \\
\hline RECA1 & GGTAAAGGGTCTATCATGCG & Waleron et al. (2002) \\
\hline RECA2c & CCTTCACCATACATAATTTGGA & \\
\hline
\end{tabular}

to the novel strains that exceeded $97 \%$. Consequently, further classification steps were focused on these species.

\section{gpd and recA sequences}

The housekeeping genes $g p d$ and recA have been evaluated previously as phylogenetic tools in discrimination of bacterial species (Brown et al., 2000; Lloyd \& Sharp, 1993). Consensus primers from the gpd gene (Table 2), applied by Brown et al. (2000) for classification of necrogenic Erwinia and Brenneria species, were used for PCR amplification of genomic DNA from the novel strains and strains of E. amylovora and E. pyrifoliae. The products were cloned into pGEM-T and the nucleotide sequences were analysed for their relationship to each other and other bacterial species (Fig. 2a and Supplementary Fig. S2a). The three novel strains were highly related and formed a cluster adjacent to several E. amylovora strains and to E. pyrifoliae. They were separated from those of E. billingiae, Erwinia mallotivora, Erwinia papayae, E. persicina, Erwinia psidii, Erwinia rhapontici, Erwinia toletana and Erwinia tracheiphila. The genus Brenneria and Dickeya chrysanthemi were more distantly related, with Pectobacterium carotovorum used as outgroup. From the novel strains, E. amylovora strains and related bacteria, parts of the recA gene were PCR amplified, cloned, sequenced and aligned. According to the alignment, the three novel strains formed a narrow group apart from E. pyrifoliae and E. amylovora (Fig. 2b and Supplementary Fig. S2b). Interestingly, strains within these species were not completely identical in their recA sequences. All three species were well separated from species of the genera Brenneria and Pectobacterium. Thus, the use of these two housekeeping genes confirmed the results of the previous analysis that classified the novel strains into a new species, separated from E. amylovora and E. pyrifoliae.

\section{Microbiological assays}

The phenotypic characteristics of the Australian isolates were compared with those of various Erwinia species listed in Table 1. The Gram-negative, facultatively anaerobic bacteria were motile, straight rods, they metabolized glucose, lacked gas production and were oxidase-negative and catalase-positive. The isolates showed the general characteristics of strains of the genus Erwinia in the family Enterobacteriaceae (Hauben \& Swings, 2005). The isolates from Australia reacted uniformly in most biochemical and physiological tests except for their reactions for galactose, inositol and xylitol. The novel strains shared some metabolic characteristics with other Erwinia species, such as acetoin production, utilization of glucose, mannitol and arabinose, the lack of arginine dihydrolase, lysine decarboxylase and ornithine decarboxylase, no production of indole, gelatinase, urease, tryptophan deaminase or $\mathrm{H}_{2} \mathrm{~S}$ and a lack of nitrate reduction. They differed in a positive reaction of $\beta$-galactosidase, they utilized citrate, but did not metabolize sorbitol, rhamnose or amygdalin, they did not reduce nitrate and did not grow at $36^{\circ} \mathrm{C}$ (Table 3). Altogether, 79

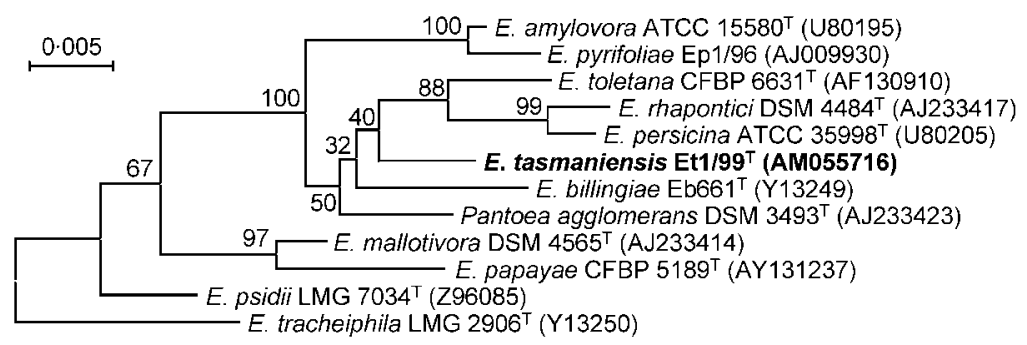

Fig. 1. Dendrogram constructed from $16 \mathrm{~S}$ rRNA gene sequences for classification of strains Et1/99 ${ }^{\top}$, Et2/99 and Et4/99 isolated in Australia from the apple and pear flora. Bootstrap values, expressed as percentages of 1000 replications, are given at branching points. Pectobacterium carotovorum ATCC $15713^{\top}$ was used as an outgroup (not shown). Accession numbers of the nucleotide sequences are provided in parentheses. 


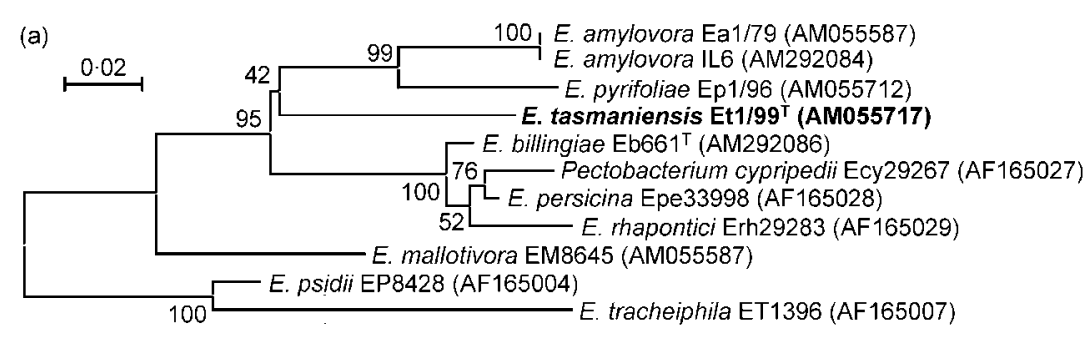

(b)

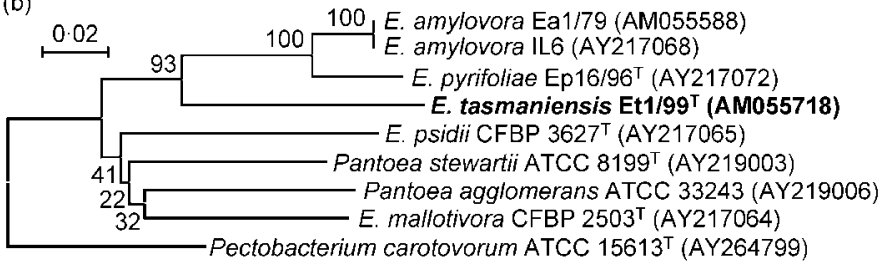

Fig. 2. Dendrograms constructed from gpd (a) and $\operatorname{rec} A$ (b) sequences for classification of strains Et1/99 ${ }^{\top}$, Et2/99 and Et4/99. Sequence accession numbers are shown in parentheses. Bootstrap values, expressed as a percentage of 1000 replications, are given at branching points. characteristics were used to construct a dendrogram showing the phenotypic distance relationships among the strains tested. Isolates Et1/99 ${ }^{\mathrm{T}}$, Et2/99 and Et4/99 clustered together in one group within $80 \%$. This group is phenotypically related to E. amylovora and E. pyrifoliae, but clearly different from the other groups (Fig. 3).

Supplementary Table S1 shows the percentage of characteristic fatty acids $(>0.5 \%)$ found in the strains tested. Palmitic acid (16:0) and palmitoleic acid $(16: 1 \omega 7 c)$ dominated, making up $50-65 \%$ of the total fatty acids. The Australian isolates showed profiles that were quantitatively and qualitatively similar, without statistically significant differences. Tridecanoic acid (13:0) was completely

Table 3. Selected physiological and biochemical characteristics of the novel strains in comparison with other Erwinia species

Strains: 1, E. persicina CFBP $3622^{\mathrm{T}}$; 2, E. rhapontici CFBP $3618^{\mathrm{T}}$; 3, E. billingiae Eb661 ${ }^{\mathrm{T}}$; 4, E. amylovora Ea1/79; 5, E. pyrifoliae Ep16/96 $;$ 6, strains Et1/99 ${ }^{\mathrm{T}}$, Et2/99 and Et4/99. The methods have been described by Fahy \& Hayward (1983).

\begin{tabular}{|lcccccc|}
\hline Test & $\mathbf{1}$ & $\mathbf{2}$ & $\mathbf{3}$ & $\mathbf{4}$ & $\mathbf{5}$ & $\mathbf{6}$ \\
\hline$\beta$-Galactosidase & + & + & + & - & - & + \\
Citrate utilization & + & + & - & - & - & + \\
Utilization of: & & & & & & \\
$\quad$ Inositol & + & + & + & - & - & $\mathrm{d}^{*}$ \\
Sorbitol & + & - & + & + & + & - \\
Rhamnose & + & + & + & - & - & - \\
Sucrose & + & + & - & + & + & + \\
$\quad$ Melibiose & + & + & + & - & - & + \\
$\quad$ Amygdalin & + & + & + & - & - & - \\
Nitrate reduction & + & + & + & - & - & - \\
Growth at $36{ }^{\circ} \mathrm{C}$ & + & - & - & - & - & - \\
Growth in $5 \% \mathrm{NaCl}$ & + & + & + & + & - & + \\
\hline
\end{tabular}

${ }^{\star}$ Negative for Et $1 / 99^{\mathrm{T}}$ and Et4/99 and positive for Et2/99. absent in these isolates. The percentage of 17:0 cyclo was low and that of $16: 1 \omega 7 c$ was relatively high compared with other Erwinia species. The dendrogram shows that the Australian isolates are significantly separated from the other Erwinia species (Fig. 4).

\section{Polyamine and protein patterns}

By using the method of Busse \& Auling (1988), diaminopropane was found to be the major polyamine compound of isolates Et1/99 ${ }^{\mathrm{T}}, \mathrm{Et} 2 / 99$ and Et4/99 (data not shown), grouping them close to E. amylovora (Zherebilo et al., 2001) by their polyamine pattern. The three strains displayed identical protein patterns when extracts of whole-cell proteins were assayed by SDS-PAGE (Fig. 5). The similarity

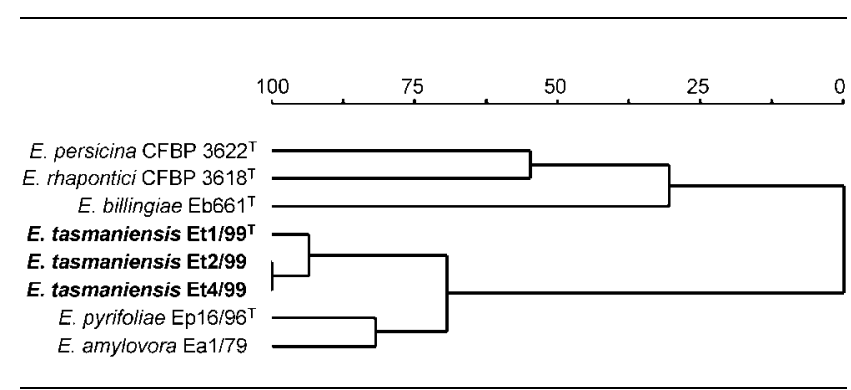

Fig. 3. Dendrogram constructed from 79 phenotypic characteristics for classification of strains Et1/99 ${ }^{\top}$, Et2/99 and Et4/99 in comparison with several other Erwinia species. In addition to physiological characteristics (Table 3 ), the strains were examined at $28^{\circ} \mathrm{C}$ in the standardized identification systems API 20E (bioMérieux), containing 22 miniaturized biochemical tests, and API 50CHE (bioMérieux), containing 49 carbon compounds, read visually after 24 and $48 \mathrm{~h}$. Inocula for the tests were prepared from $24-48 \mathrm{~h}$ cultures grown on Stl agar (Merck) at $28^{\circ} \mathrm{C}$ for E. amylovora, E. billingiae, E. persicina, E. rhapontici, E. pyrifoliae and the novel strains. The distance matrix was calculated by using Euclidean distances and cluster analysis was done with the nearest-neighbour method (single linkage) (PC-ORD, version 4.14; MjM software). 


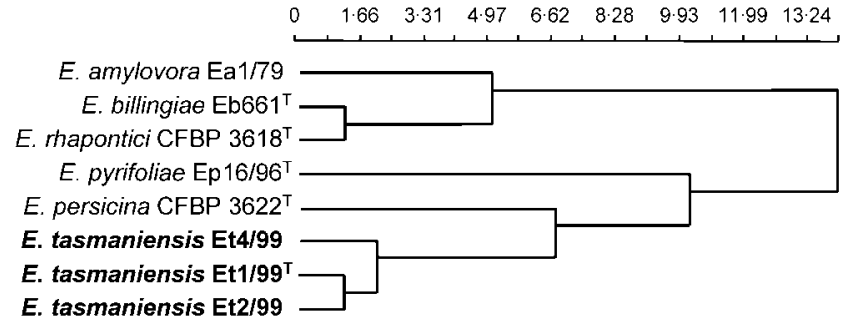

Fig. 4. Dendrogram (UPGMA clustering method, Euclidian distance) constructed from whole-cell fatty acids for classification of strains Et1/99 ${ }^{\top}$, Et2/99 and Et4/99.

to reference strains of the species E. amylovora and E. pyrifoliae was lower.

\section{DNA-DNA hybridizations}

The DNA base composition of the isolates was in a narrow range between $50 \cdot 5$ and $52 \cdot 4 \mathrm{~mol} \% \mathrm{G}+\mathrm{C}$. The results of DNA-DNA hybridizations confirmed that the three isolates Et1/99 ${ }^{\mathrm{T}}$, Et2/99 and Et4/99 were highly related (Table 4). DNA-DNA relatedness provides a single species definition that can be applied equally to the genomes of all bacteria without limitation to single genes. A phylogenetic definition of a species (genomospecies) was formulated as strains with approximately $70 \%$ or greater DNA-DNA relatedness by Wayne et al. (1987). The degree of binding in reassociation experiments with DNA from reference strains of $E$. amylovora, E. billingiae, E. persicina, E. pyrifoliae and E. rhapontici was well below $70 \%$ (Table 4), indicating that the Erwinia isolates from Australia belong to a species different from the other Erwinia species.

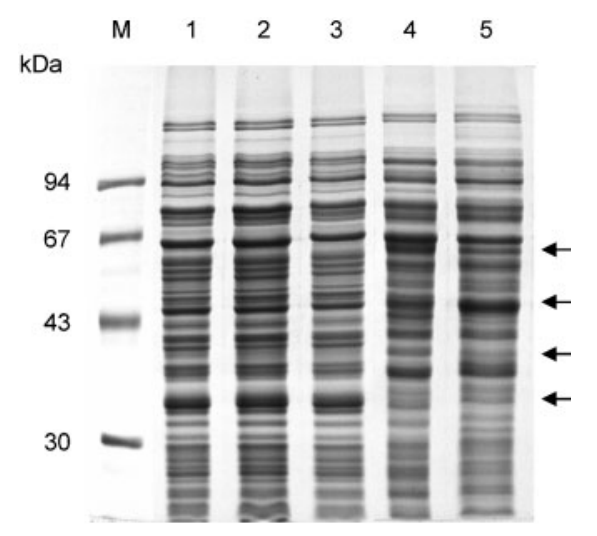

Fig. 5. Protein gel from cell extracts of several Erwinia strains. Lanes: M, protein size markers; 1, E. tasmaniensis Et4/99; 2, E. tasmaniensis $\mathrm{Et} 1 / 99^{\mathrm{T}}$; 3, E. tasmaniensis Et2/99; 4, E. pyrifoliae Ep1/96; 5, E. amylovora Ea1/79. Some characteristic bands for $E$. tasmaniensis strains in comparison with the other erwinias are marked with arrows. The protocol of Busse et al. (1989) was used for SDS-PAGE of soluble proteins.
Table 4. Levels of DNA-DNA reassociation among strains Et1/99 ${ }^{\top}$, Et2/99 and Et4/99 and strains of $E$. amylovora and E. pyrifoliae

Hybridization studies with labelled DNA of strain Et $1 / 99^{\mathrm{T}}$ were done as described by Auling et al. (1986) using the optical method of De Ley et al. (1970) for measurement of initial renaturation rates. The concentrations of DNA were determined chemically according to Richards (1974).

\begin{tabular}{|c|c|}
\hline Strain & Relative DNA binding (\%) \\
\hline \multicolumn{2}{|l|}{ E. tasmaniensis sp. nov. } \\
\hline Et1/99 ${ }^{\mathrm{T}}$ & 100 \\
\hline Et2/99 & 100 \\
\hline Et4/99 & 100 \\
\hline \multicolumn{2}{|l|}{ E. amylovora } \\
\hline $\mathrm{Ea} 1 / 79$ & 43 \\
\hline CFBP $1232^{\mathrm{T}}$ & 51 \\
\hline E. billingiae Eb661 ${ }^{\mathrm{T}}$ & 56 \\
\hline E. persicina CFBP $3622^{\mathrm{T}}$ & 54 \\
\hline \multicolumn{2}{|l|}{ E. pyrifoliae } \\
\hline Ep1/96 & 58 \\
\hline Ep16/96 & 58 \\
\hline E. rhapontici CFBP $3618^{\mathrm{T}}$ & 44 \\
\hline
\end{tabular}

\section{Conclusions}

According to the microbiological and molecular results, we propose to classify the described levan-producing strains from apple and pear into a novel species, named Erwinia tasmaniensis sp. nov., with Et $1 / 99^{\mathrm{T}}$ as the type strain. The isolated bacteria are distinct from E. amylovora or the Asianpear-pathogenic species E. pyrifoliae according to several criteria, including their inability to cause disease symptoms on immature pears or necrosis on apple seedlings. API tests, DNA-DNA hybridization and nucleotide sequence analysis allow them to be classified into the novel species $E$. tasmaniensis. Two other isolates, Et2/99 and Et4/99, were highly related in many properties. The classification of the levan-producing bacteria into the genus Erwinia has added a novel species into a group of mostly necrogenic bacteria. After transfer of the Erwinia herbicola group to the genus Pantoea, E. tasmaniensis is a second non-pathogenic species in the genus Erwinia in addition to E. billingiae (Mergaert et al., 1999). Similarities above $97 \%$ for 16 S rRNA gene sequences may indicate a high relationship of strains and additional parameters may be needed for species classification (Gevers et al., 2005). Nevertheless, the $16 \mathrm{~S}$ rRNA gene sequence trees that we constructed showed the same monophyletic groups as the trees from $g p d$ and $r e c A$ genes. Minor differences that were observed in the positions of the groups relative to each other are in agreement with previous phylogenetic analysis of these two and several other housekeeping genes (Wertz et al., 2003). Thus, we concluded that the gpd and recA genes can also be used to discriminate between E. amylovora and related species. 


\section{Description of Erwinia tasmaniensis sp. nov.}

Erwinia tasmaniensis (tas.ma.ni.en'sis. N.L. fem. adj. tasmaniensis pertaining to Tasmania, where the type strain was isolated).

Cells are Gram-negative, non-spore-forming, motile, straight rods, measuring $0 \cdot 5-1$ by $1 \cdot 5-2 \mu \mathrm{m}$. Facultatively anaerobic, oxidase-negative and catalase-positive. The species has all of the characteristics of the genus Erwinia. Colonies on Standard I agar (StI; Merck) are light-beige, circular, smooth, translucent, flat to slightly convex and about $3 \mathrm{~mm}$ in diameter after $24-48 \mathrm{~h}$ at $28^{\circ} \mathrm{C}$. No diffusible or fluorescent pigment is observed. Strains grow well on StI agar and nutrient agar at $28^{\circ} \mathrm{C}$, but not at $36^{\circ} \mathrm{C}$. They are able to grow in $5 \% \mathrm{NaCl}$. Glucose is fermented without gas production. Arginine dihydrolase, lysine decarboxylase, ornithine decarboxylase, urease, gelatinase and tryptophan deaminase are not produced, but $\beta$-galactosidase is present. Indole and $\mathrm{H}_{2} \mathrm{~S}$ are not produced. There is acetoin production. Nitrates are not reduced. The following carbon sources are utilized at $28^{\circ} \mathrm{C}$ within 3 days: L-arabinose, ribose, glucose, fructose, galactose (except strain Et4/99), mannitol, $\mathrm{N}$-acetylglucosamine, sucrose, trehalose, melibiose (weak) and citrate. The following carbon sources are not utilized at $28^{\circ} \mathrm{C}$ within 3 days: sorbitol, rhamnose, amygdalin, glycerol, erythritol, Darabinose, D-xylose, $\mathrm{L}$-xylose, adonitol, methyl $\beta$-D-xyloside, mannose, sorbose, dulcitol, inositol (except strain Et2/99), methyl $\alpha$-D-mannoside, methyl $\alpha$-D-glucoside, arbutin, aesculin, salicin, cellobiose, maltose, lactose, inulin, melezitose, raffinose, starch, glycogen, xylitol (except strain Et2/99), gentiobiose, D-turanose, D-lyxose, D-tagatose, D-fucose, Lfucose, D-arabitol, L-arabitol, gluconate, 2-ketogluconate and 5-ketogluconate. The $\mathrm{G}+\mathrm{C}$ contents of strains Et1/99 ${ }^{\mathrm{T}}$, Et2/99 and Et $4 / 99$ are $50 \cdot 5-52 \cdot 4 \mathrm{~mol} \%$ as determined by the $T_{\mathrm{m}}$ method. The known strains were isolated from the phyllosphere, in particular apple flowers, pear flowers and bark of apple trees. The species may also occur on other plant surfaces and may also be found outside Australia.

The type strain, Et $1 / 99^{\mathrm{T}}\left(=\right.$ DSM $\left.17950^{\mathrm{T}}=\mathrm{NCPPB} 4357^{\mathrm{T}}\right)$, was collected in Tasmania from apple flowers. Strain Et2/99 $(=\mathrm{DSM} 17949=\mathrm{NCPPB} 4358)$ was isolated from pear flowers in Victoria and strain Et4/99 was isolated from apple bark in Queensland.

\section{Acknowledgements}

We thank Peter Merriman (Knoxfield), Darby Munro (Hobart) and Christopher Hayward (Brisbane) for providing facilities and support for the isolation of bacteria from apple and pear. We also acknowledge the technical assistance of Inge Reupke in DNA hybridization analysis and comments on the manuscript by Christopher Hayward and Bernd Schneider.

\section{References}

Auling, G., Probst, A. \& Kroppenstedt, R. M. (1986). Chemo- and molecular taxonomy of $\mathrm{D}(-)$-tartrate-utilizing pseudomonads. Syst Appl Microbiol 8, 114-120.
Bascomb, S. \& Manafi, M. (1998). Use of enzyme tests in characterization and identification of aerobic and facultatively anaerobic Gram-positive cocci. Clin Microbiol Rev 11, 318-340.

Brown, E. W., Davis, R. M., Gouk, C. \& van der Zwet, T. (2000). Phylogenetic relationships of necrogenic Erwinia and Brenneria species as revealed by glyceraldehyde-3-phosphate dehydrogenase gene sequences. Int J Syst Evol Microbiol 50, 2057-2068.

Busse, J. \& Auling, G. (1988). Polyamine pattern as a chemotaxonomic marker within the Proteobacteria. Syst Appl Microbiol 11, 1-8.

Busse, H. J., El-Banna, T. \& Auling, G. (1989). Evaluation of different approaches for identification of xenobiotic degrading pseudomonads. Appl Environ Microbiol 55, 1578-1583.

Cerny, G. (1976). Method for distinction of the Gram-negative from Gram-positive bacteria. Eur J Appl Microbiol Biotechnol 3, 223-225.

De Ley, J., Cattoir, H. \& Reynaerts, A. (1970). The quantitative measurement of DNA hybridization from renaturation rates. Eur J Biochem 12, 133-142.

Fahy, P. C. \& Hayward, A. C. (1983). Media and methods for isolation and diagnostic tests. In Plant Bacterial Diseases - a Diagnostic Guide, pp. 337-375. Edited by P. C. Fahy \& G. J. Persley. Sydney: Academic Press.

Falkenstein, H., Bellemann, P., Walter, S., Zeller, W. \& Geider, K. (1988). Identification of Erwinia amylovora, the fireblight pathogen, by colony hybridization with DNA from plasmid pEA29. Appl Environ Microbiol 54, 2798-2802.

Gevers, D., Cohan, F. M., Lawrence, J. G. \& 8 other authors (2005). Re-evaluating prokaryotic species. Nat Rev Microbiol 3, 733-739.

Gregersen, T. (1978). Rapid method for distinction of Gramnegative from Gram-positive bacteria. Eur J Appl Microbiol Biotechnol 5, 123-127.

Hao, M. V., Brenner, D. J., Steigerwalt, A. G., Kosako, Y. \& Komagata, K. (1990). Erwinia persicinus, a new species isolated from plants. Int J Syst Bacteriol 40, 379-383.

Hauben, L. \& Swings, J. (2005). Genus XIII. Erwinia Winslow, Broadhurst, Buchanan, Krumweide, Rogers and Smith 1920, $209^{\mathrm{AL}}$. In Bergey's Manual of Systematic Bacteriology, 2nd edn, vol. 2, part B, pp. 670-679. Edited by D. J. Brenner, N. R. Krieg, J. R. Staley \& G. M. Garrity. New York: Springer.

Hauben, L., Moore, E. R. B., Vauterin, L., Steenackers, M., Mergaert, J., Verdonck, L. \& Swings, J. (1998). Phylogenetic position of phytopathogens within Enterobacteriaceae. Syst Appl Microbiol 21, 384-397.

Johnson, K. B. \& Stockwell, V. O. (2000). Biological control of fire blight. In Fire Blight: the Disease and its Causative Agent Erwinia amylovora, pp. 319-337. Edited by J. Vanneste. Wallingford, UK: CABI Publishing.

Jukes, T. H. \& Cantor, C. R. (1969). Evolution of protein molecules. In Mammalian Protein Metabolism, pp. 21-132. Edited by H. N. Munro. New York: Academic Press.

Kim, W.-S., Gardan, L., Rhim, S.-L. \& Geider, K. (1999). Erwinia pyrifoliae sp. nov., a novel pathogen that affects Asian pear trees (Pyrus pyrifolia Nakai). Int J Syst Bacteriol 49, 899-905.

Kim, W.-S., Jock, S., Paulin, J.-P., Rhim, S.-L. \& Geider, K. (2001). Molecular detection and differentiation of Erwinia pyrifoliae and host range analysis of the Asian pear pathogen. Plant Dis 85, 1183-1188.

Kowalczykowski, S. C., Dixon, D. A., Eggleston, A. K., Lauder, S. D. \& Rehrauer, W. M. (1994). Biochemistry of homologous recombination in Escherichia coli. Microbiol Rev 58, 401-465.

Kumar, S., Tamura, K. \& Nei, M. (2004). MEGA3: integrated software for molecular evolutionary genetics analysis and sequence alignment. Brief Bioinform 5, 150-163. 
Lloyd, A. T. \& Sharp, P. M. (1993). Evolution of the recA gene and the molecular phylogeny of bacteria. J Mol Evol 37, 399-407.

Mergaert, J., Hauben, L., Cnockaert, M. C. \& Swings, J. (1999). Reclassification of non-pigmented Erwinia herbicola strains from trees as Erwinia billingiae sp. nov. Int J Syst Bacteriol 49, 377-383.

Richards, G. M. (1974). Modification of the diphenylamine reaction giving increased sensitivity and simplicity in the estimation of DNA. Anal Biochem 57, 369-376.

Suslow, T. V., Schroth, M. N. \& Isaka, M. (1982). Application of a rapid method for Gram-differentiation of plant pathogenic and saprophytic bacteria without staining. Phytopathology 72, 917-918.

Vanneste, J. (editor) (2000). Fire Blight: the Disease and its Causative Agent Erwinia amylovora. Wallingford, UK: CABI Publishing.

Waleron, M., Waleron, K., Podhajska, A. J. \& kojkowska, E. (2002).

Genotyping of bacteria belonging to the former Erwinia genus by
PCR-RFLP analysis of a recA gene fragment. Microbiology 148, 583-595.

Wayne, L. G., Brenner, D. J., Colwell, R. R. \& 9 other authors (1987). Report of the ad hoc committee on reconciliation of approaches to bacterial systematics. Int J Syst Bacteriol 37, 463-464.

Weisburg, W. G., Barns, S. M., Pelletier, D. A. \& Lane, D. J. (1991). $16 \mathrm{~S}$ ribosomal DNA amplification for phylogenetic study. J Bacteriol 173, 697-703.

Wertz, J. E., Goldstone, C., Gordon, D. M. \& Riley, M. A. (2003). A molecular phylogeny of enteric bacteria and implications for a bacterial species concept. J Evol Biol 16, 1236-1248.

Zherebilo, O. E., Kucheryava, N., Gvozdyak, R. I., Ziegler, D., Scheibner, M. \& Auling, G. (2001). Diversity of polyamine patterns in soft rot pathogens and other plant-associated members of the Enterobacteriaceae. Syst Appl Microbiol 24, 54-62. 